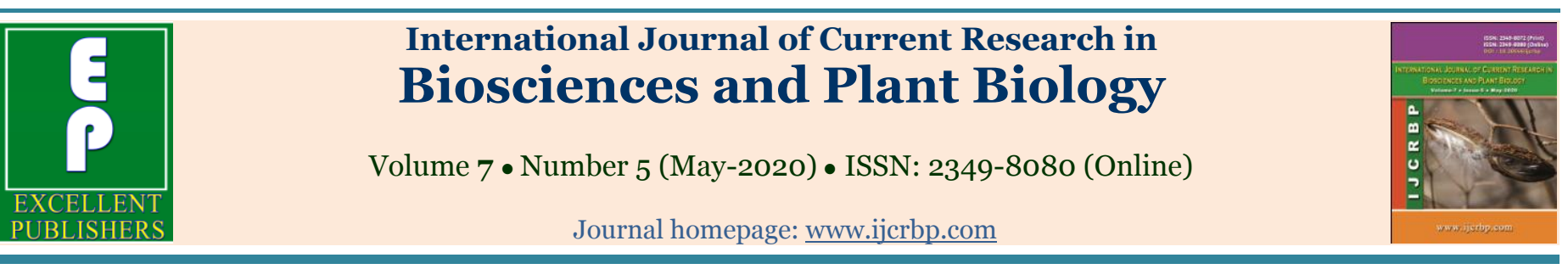

\title{
Strategies for phytoremediation of soil contaminated with lead using Alternanthera sessilis
}

\author{
S. Kavi Malar and M. Saradha* \\ Department of Botany, Nirmala College for Women, Coimbatore-641 018, Tamil Nadu, India

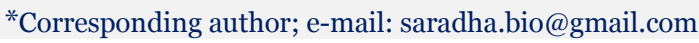

\begin{tabular}{l}
\hline Article Info \\
\hline Date of Acceptance: \\
15 April 2020 \\
Date of Publication: \\
06 May 2020
\end{tabular}

Keywords

Heavy metal

Lead

Minimum inhibitory

concentration

Phytoremediation

\begin{abstract}
The present study was performed to explore the potential of Alternanthera sessilis for remediation of toxic inorganic pollutants. Minimum inhibitory concentration was determined against inorganic pollutants lead $(\mathrm{Pb})$. The minimum inhibitory concentration was observed. The plant was able to utilize lead at 1000ppm and also can resist toxic heavy metal in the polluted soil sites. The shoot and root length was higher in plant treated in $1000 \mathrm{ppm}$ of lead than other treatment. The growth and metabolism of $A$. sessilis were affected variably by the heavy metal lead. Highest concentration of growth shows the withstanding capacity of the plant in the heavy metal contaminated soil.
\end{abstract}

\section{Introduction}

Phytoremediation referring to the technology that uses living plants to clean up the soil and water contaminated with hazardous pollutants (Naureen et al., 2020). Phytoremediation for heavy metal contaminated soils was on track around 40 years ago. For phytoremediation four processes are documented: phytoextraction, phytostabilazation, phytovolatilization, and rhizofiltration. Phytoextraction is an effective tool for removing heavy metals from the contaminated soil into plant tissues (Abbas and Abdelhafez, 2013); subsequently, it can be easily and safely processed or recycled, through ashing, composting of drying (Lasat, 2000). The plants for phytoremediation are carefully chosen based on their root depth, the nature of the contaminants, soil, and based on the climate. The root depth directly influences the depth of soil that can be remediated. It varies greatly among different types of plant and also vary considerably for one species to another depending upon contaminant concentration (Tangahu et al., 2011). Some plant roots can absorb and immobilize heavy metal pollutants, while other plant species have the capability of metabolizing or accumulating organic and nutrient contaminants. Using of green plants with soil and agro-techniques to remove the soil contaminants is a cost effective and harmless plant based remediation (Subhashini et al., 2017). The selection of plant species for phytoextraction of 
heavy metals depends mainly on the ability of tolerant capacity and the biomass (Rezania et al., 2016). Therefore the selected plant $A$. sessilis has heavy metal tolerating capacity for successful of phytoremediation. It belongs to the family Amaranthaceae. It is commonly called as Sessile Joyweed found in and near ponds, canals and reservoirs. The main aim of the study is to monitor the potential of the phytoremediation on treating heavy metal contaminated soil site, and to provide a keen idea about heavy metal absorption mechanisms by selected plant species $A$. sessilis also to know the fate of the heavy metals in selected plant species especially on $\mathrm{Pb}$.

\section{Materials and methods}

\section{Soil analysis}

Soil samples were collected from the polluted area of Pattanamputhur, Coimbatore district, Tamil Nadu. A particular site at the polluted area was selected and the surface litter at the sampling spot was cleaned. The spot is ploughed at the depth of $15 \mathrm{~cm}$. The 'V' shaped cut was made to a depth of $15 \mathrm{~cm}$ in the sampling spot. Thick slices of soil from top to bottom of exposed on ' $\mathrm{V}$ ' shaped cut was removed, and placed in a basin. The sample is mixed thoroughly and the foreign materials like roots, stones, pebbles were removed. Quartering is done by dividing the mixed sample into four equal parts. The two opposite quarters are discarded and the remaining two are remixed. The remixed soil was collected and taken to the laboratory using labelled clean cloth bag. The soil was analysed for the presence of heavy metals $\mathrm{Pb}$ using AAS (Atomic Absorption Spectrophotometer).

\section{Determination of heavy metal using the AAS}

The machine was energized and kept for about 15 minutes to stabilize. Wavelength recommended for heavy metal $(\mathrm{Pb})$ absorption was selected. Air and acetylene flow into burner system was adjusted and regulated. Other essential settings as was recommended in the standard procedure were adjusted. To one gram of sample, $20 \mathrm{ml}$ of aquaregia was added in the ratio of $3: 1$ (Hydrochloric acid): (Nitric acid). It was kept undisturbed for 8 hours overnight, and the observance of the yellow with orange colour was noted. After the change of colour they were kept in sand bath for $4-5$ hours. The colour change from yellow orange colour to pure white crystal clear solution was noted, and mixed with $20 \mathrm{ml}$ of distilled water. The solution was filtered using Whatman no. 42 filter paper. Using double distilled water the volume was made up to $100 \mathrm{ml}$. The concentration of heavy metal $(\mathrm{Pb})$ in the sample was determined using AAS (Salt et al., 1998).

\section{Soil collection and pot culture preparation}

The red soil was collected from the unpolluted area. The collected soil was well fractioned using the stainless steel sieve to remove the large particles like stones. Further any stones were removed by hand. Soil was added to pots with differently labelled as T1, T2, T3 and control.

\section{Phytoremediation experiment}

The selected plant species of $A$. sessilis was planted in the pots. The shoot length of the potted plants was noted. The potted plants were treated with different concentrations of $\mathrm{Pb} 500 \mathrm{ppm}$ (T1), 1000ppm (T2), and 1500 ppm (T3). The control plant is treated with water and was kept in the sunlight. The plants were monitored for four weeks for the growth, and the length of the plant was also observed.

\section{Plant metal concentration analysis}

The plants were harvested from the planted pots, and separated into roots and shoots at the end of the fourth week. The plant samples (shoot and root) were washed with de - ionized water, cut into small pieces, air dried and then oven dried at room temperature and weighed for dry biomass. Dried plant samples were ground, and packed in a labelled ziplock cover to determine the heavy metal concentration by AAS (Atomic Absorption Spectrophotometer). Total metal uptake in each pot was determined by using AAS.

\section{Statistical analysis}

Statistical analyses were performed using the SPSS (version 20). Differences in heavy metal 
concentrations were detected using one-way ANOVA, followed by multiple comparisons using Duncan tests. A significance level of $(P<0.05)$ was used throughout the study.

\section{Results}

\section{Phytoremediation in contaminated soil}

Phytoremediation study was carried out in Pattanampudur area, Coimbatore district, Tamil Nadu. The Noyyal River flows through the selected area. The river and surrounding areas are highly contaminated by heavy metals because of discharge of industrial effluents into water bodies. The contaminated soil was collected from the selected area and analyzed for the accumulation of $\mathrm{Pb}$ concentration by using AAS. The content of $\mathrm{Pb}$ was higher $(13.60 \mathrm{mg} / \mathrm{kg})$ in the selected contaminated area.

\section{Analysis of heavy metal concentration in the plant species}

The composition of leaf in the treated $A$. sessilis is shown in Table 1. The results revealed that the $A$. sessilis treated with $1000 \mathrm{ppm}$ concentration of $\mathrm{Pb}$ absorbs high amount of $\mathrm{Pb}$ than the other treatment. The plant was able to utilize $\mathrm{Pb}$ at 1000 ppm and also can resist toxic heavy metal in the polluted soil sites.

The shoot and root length of $A$. sessilis before and after treatment is noted in Table 2. The shoot and root length was higher in plant treated in 1000 $\mathrm{ppm}$ of $\mathrm{Pb}$ than other treatment. The growth and metabolism of $A$. sessilis were affected variably by the heavy metal $\mathrm{Pb}$. Highest concentration of growth shows the withstanding capacity of the plant in the heavy metal contaminated soil.

\section{Composition of heavy metals in plant tissues}

The heavy metals $(\mathrm{Pb})$ analysis was done for $\mathrm{T} 1$, T2, T3 and control plants. The result of the study revealed that the higher concentration of heavy metal $(\mathrm{Pb})$ was found in the T2, whereas the least concentration of heavy metals was recorded in the control. Thus the phytoremediation is the effective process in the removal of heavy metals contaminated soil. The plants withstanding the level of contamination, depends on the accumulation capacity on it. Moreover phytoremediation by $A$. sessilis has been proved to be useful in remediating the contaminated sites.

Table 1. The composition of heavy metals in the treated A. sessilis.

\begin{tabular}{lll}
\hline Element & Parameters & Total Lead (mg/kg) \\
\hline $\mathrm{Pb}$ & Control & $6.20 \pm 0.28$ \\
$\mathrm{~Pb}$ & Treatment 1 (500 ppm) & $12.5 \pm 0.68$ \\
$\mathrm{~Pb}$ & Treatment 2 (1000 ppm) & $20.8 \pm 0.43$ \\
$\mathrm{~Pb}$ & Treatment 3 (1500 ppm) & $13.4 \pm 0.39$ \\
\hline
\end{tabular}

Values are means of three replicates \pm standard error.

Table 2. Effect of lead in the shoot and root length of A. sessilis.

\begin{tabular}{lllll}
\hline \multirow{2}{*}{ Treatments } & \multicolumn{2}{l}{ Shoot length (cm) } & \multicolumn{2}{l}{ Root length (cm) } \\
\cline { 2 - 5 } & Before & After & Before & After \\
\hline Control & $39 \pm 3.24^{\mathrm{ab}}$ & $43 \pm 2.0^{\mathrm{b}}$ & $13 \pm 0.84^{\mathrm{b}}$ & $15 \pm 1.0^{\mathrm{b}}$ \\
Treatment 1 (500 ppm) & $40 \pm 2.31^{\mathrm{a}}$ & $42 \pm 1.53^{\mathrm{c}}$ & $9 \pm 1.0^{\mathrm{c}}$ & $11.5 \pm 2.0^{\mathrm{c}}$ \\
Treatment 2 (1000 ppm) & $37 \pm 1.53^{\mathrm{b}}$ & $45 \pm 1.0^{\mathrm{a}}$ & $13.5 \pm 1.0^{\mathrm{a}}$ & $14 \pm 1.8^{\mathrm{a}}$ \\
Treatment 3 (1500 ppm) & $30 \pm 2.43^{\mathrm{c}}$ & $39 \pm 2.56^{\mathrm{d}}$ & $11.5 \pm 2.4^{\mathrm{b}}$ & $12 \pm 2.9^{\mathrm{b}}$ \\
\hline
\end{tabular}

Values are means of three replicates \pm standard error. Means followed by different letter(s) in the column are significant to each other at $5 \%$ level according to DMRT. 


\section{Discussion}

This study was performed to identify the ability of $A$. sessilis for the removal of $\mathrm{Pb}$ from the contaminated sites. The obtained results showed that $A$. sessilis has the ability to accumulate $\mathrm{Pb}$ in its tissues (shoot and root). However the accumulation of $\mathrm{Pb}$ in plant tissues was more favourable in 1000 ppm than 500 and $1500 \mathrm{ppm}$. This may be due to the fact that at moderately low concentration of $\mathrm{Pb}$ in soil, plants tend to accumulate more metals than higher concentrations (Benzarti et al., 2008). The studies reported that $\mathrm{Pb}$ was found in the sampled soils as well as accumulated in the plant also was analyzed. The plants uptake metals in varying degrees which are grown in metal contaminated soils. Plant metal uptake is largely influenced by the availability of metals, which is in turn determined by both soil-associated factors (Greger, 1999).

In the present study $\mathrm{Pb}$ metal ion was added in soluble forms to ensure their high availability for plant uptake. However, there were differences between the same plant in shoot and root length of plant grown on soil with different concentration of $\mathrm{Pb}$ (Table 2). Similar result was reported by Alaboudi et al. (2018) in Helianthus annuus. The results showed that the shoot, root weight and length significantly decreased when the plants grown on soil amended with $200 \mathrm{mg} \mathrm{kg}^{-1}$ soil of $\mathrm{Pb}$ and $\mathrm{Cd}$, respectively. Therefore phytoremediation may provide a sustainable option to remediate $\mathrm{Pb}$ contaminated soils (Aransiola et al., 2013). Phytoremediation has gained extensive attention and much progress in remediation of inorganic and organic contaminants for the means of enhanced phytoremediation (Kamal et al., 2019). Finally the trace amount of $\mathrm{Pb}$ in the contaminated soil recommends $A$. sessilis plant to be safely and economically for cleaning up soils contaminated with $\mathrm{Pb}$.

\section{Conclusion}

From this study the plant treated with $1000 \mathrm{ppm}$ has higher uptake of $\mathrm{Pb} 20.8 \mathrm{mg} / \mathrm{kg}$ than $500 \mathrm{ppm}$ and $1500 \mathrm{ppm}$. It was concluded that plant $A$. sessilis can tolerate to heavy metals, can be attributed to the accumulators of $\mathrm{Pb}$, can be successfully used in the phytoremediation of heavy metals contaminated sites and remediate contaminated soils. Therefore it is a reasonable choice for remediation of the contaminated sites. It can be suggested that this study provided valuable data supporting the use of $A$. sessilis in phytoremediation.

\section{Conflict of interest statement}

Authors declare that they have no conflict of interest.

\section{Acknowledgement}

Authors are greatly thankful to the Principal, Nirmala College for Women, Coimbatore for giving constant support and facilities to carry out this research work.

\section{References}

Abbas, M. H. H., Abdelhafez, A. A., 2013. Role of EDTA in arsenic mobilization and its uptake by maize grown on an As-polluted soil. Chemosphere. 90, 588-594.

Alaboudi, K. A., Ahmed, B., Brodi, G., 2018. Phytoremediation of $\mathrm{Pb}$ and $\mathrm{Cd}$ contaminated soils by using sunflower (Helianthus annuus) plant. Ann. Agric. Sci. 63(1), 123-127.

Aransiola, S. A., Josiah Ijah, U. J., Abioye, O. P., 2013. Phytoremediation of lead polluted soil by Glycine max L. Appl. Environ. Soil Sci. 2013, Article ID 631619, 1-7.

Benzarti, S., Mohri, S., Ono, Y., 2008. Plant response to heavy metal toxicity: comparative study between the hyperaccumulator Thlaspi caerulescens (ecotype ganges) and nonaccumulator plants: lettuce, radish, and alfalfa. Environ. Toxicol. 23(5), 607-616.

Greger, M., 1999. Metal availability and bioconcentration in plants. In: M.N.V. Prasad, J. Hagemeyer (Eds.), Heavy Metal Stress in Plants-From Molecules to Ecosystems, Springer Press, Berlin, pp.1-27.

Kamal, U., Mohammad, A. A., Mohammed, H. A., 2019. The assessment of cadmium, chromium, copper and nickel tolerance and bioaccumulation by shrub plant Tetraena qataranse. Sci. Rep. 9, 5658.

Lasat, M., 2000. Phytoextraction of metals from contaminated soil: a review of plant/soil/metal interaction and assessment of pertinent agronomic issues. J. Hazard. Subst. Res. 2(5), $1-25$. 
Naureen, N., Iqra, T., Abdul, M., Muhammad, A., Sana, S., 2020. Review article on phytoremediation and other remediation technologies of soil contaminated with heavy metals. Acta Scient. Agric. 4(3), 1-5.

Rezania, S., Taib, S. M., Md Din, M. F., Dahalan, F. A., Kamyab, H., 2016. Comprehensive review on phytotechnology: heavy metals removal by diverse aquatic plants species from wastewater. J. Hazard. Mater. 318, 587-599.

Salt, D. E., Smith, R., Raskin, I., 1998.
Phytoremediation. Annu. Rev. Plant Physiol. Plant Mol. Biol. 49(1), 643-668.

Subhashini, V., Swamy, A. V. V. S., Harika, D., Venkateswararao, K., 2017. Phytoremediation of heavy metals contaminated soils. Int. J. Curr. Microbiol. App. Sci. 5, 19-30.

Tangahu, B. V., Abdullah, S. R. S., Basri, H., Idris, M., Anuar, N., Mukhlisin, M., 2011. A Review on heavy metals (As, $\mathrm{Pb}$, and $\mathrm{Hg}$ ) uptake by plants through phytoremediation. Int. J. Chem. Eng. 2011, Article ID 939161, 1-31.

\section{How to cite this article:}

Kavi Malar, S., Saradha, M., 2020. Strategies for phytoremediation of soil contaminated with lead using Alternanthera sessilis. Int. J. Curr. Res. Biosci. Plant Biol. 7(5), 46-50.

doi: https://doi.org/10.20546/ijcrbp.2020.705.007 